\title{
EFEK MODERASI SIZE DALAM PENGUNGKAPAN SUKARELA: BUKTI EMPIRIS DI BURSA EFEK INDONESIA
}

\author{
Wendy * \\ Universitas Tanjungpura, Indonesia
}

\begin{abstract}
The purpose of this study is to analyze the determinants of voluntary disclosure (VD) by using three non-interaction models and one interaction model. This paper observes four VD's determinants (ownership dispersion, managerial ownership, audit committee, and independent commissioners), one control variable (capital structure), and one moderating variable (total asset). By using panel data analysis (225 observations) on the Indonesia Stock Exchange (IDX), it is found that the total asset can be used as the moderating variable in explaining the determinants of VD in IDX. Furthermore, the interaction model shows better results than non-interaction models. Managerial ownership, independent commissioners, and ownership dispersion show high consistency with the tested hypotheses. This is different from the audit committee which does not support the hypothesis. These findings implicate managerial policies that need to consider good corporate governance in supporting the voluntary disclosure of public companies in Indonesia. Strengthening external validity in the form of replication, developing research models, and refining research methods is needed to strengthen the managerial implications. Testing the robustness by simulating various substitute proxies to optimize the generalization of research findings needs to be considered in future studies.
\end{abstract}

JEL : G32, G34.

Keywords : voluntary disclosure, size, ownership dispersion, managerial ownership, audit committee.

\begin{abstract}
ABSTRAK
Artikel ini bertujuan menganalisis determinan pengungkapan sukarela menggunakan tiga model tanpa interaksi dan satu model dengan interaksi. Penelitian dilakukan dengan mengobservasi empat deteminan pengungkapan sukarela (kepemilikan menyebar, kepemilikan manajerial, komite audit, dan komisaris independen), satu variabel kontrol (struktur modal), dan satu variabel moderasi (total aktiva). Dengan menggunakan analisis data panel (225 observasi) pada Bursa Efek Indonesia (BEI), ditemukan bahwa total aktiva dapat digunakan sebagai pemoderasi dalam menjelaskan determinan pengungkapan sukarela di BEI. Lebih jauh, model dengan interaksi menunjukkan hasil yang lebih baik dibandingkan model tanpa interaksi. Kepemilikan manajerial, komisaris independen, dan kepemilikan yang menyebar menunjukkan konsistensi yang tinggi terhadap hipotesishipotesis yang diuji. Hal ini berbeda dengan komite audit yang tidak mendukung hipotesis. Temuan-temuan dalam penelitian ini berimplikasi pada kebijakan manajerial yang perlu mempertimbangkan tata kelola yang baik dalam mendukung pengungkapan sukarela perusahaan-perusahaan terbuka di Indonesia. Penguatan validitas eksternal berupa replikasi, pengembangan model riset, dan penyempurnaan metode penelitian diperlukan untuk memperkuat implikasi manajerial tersebut. Pengujian kehandalan model dengan menyimulasikan berbagai proksi pengganti agar generalisasi hasil riset lebih optimal perlu dipertimbangkan pada penelitian-penelitian selanjutnya.
\end{abstract}

Kata Kunci : pengungkapan sukarela, ukuran perusahaan, kepemilikan menyebar, kepemilikan manajerial, komite audit.

*Email : wendy@ekonomi.untan.ac.id

Received : 25-10-2019, Accepted : 09-01-2020, Published : 28-04-2020.

P-ISSN : 2087-9954, E-ISSN : 2550-0066. DOI : http://dx.doi.org/10.26418/jebik.v9i1.37244 


\section{PENDAHULUAN}

Undang-Undang Pasar Modal nomor 8 tahun 1995 menjelaskan bahwa masyarakat berhak mengetahui kondisi perusahaan agar tidak menimbulkan kerugian pada investasi mereka. Peraturan tersebut secara eksplisit mewajibkan perusahaan mengungkap informasi yang lengkap dan transparan guna memenuhi kebutuhan investor. Informasi yang transparan dan komprehensif menjadi salah satu pedoman dalam pengambilan keputusan investasi di masa depan (Fatmawati et al., 2018). Pengungkapan berhubungan dengan Informasi laporan keuangan dan informasi tambahan berupa posstatement events, footnote, forecast keuangan, dan analisis manajemen (Astika, 2011). Pengungkapan juga berperan sebagai tanda (sinyal) yang dapat memengaruhi keputusan investasi berisiko para pemodal.

Heriyanthi (2013) menjelaskan dua jenis pengungkapan, yaitu wajib (mandatory disclosure) dan sukarela (voluntary disclosure). Mandatory disclosure merupakan pengungkapan yang harus dilakukan perusahaan sesuai dengan aturan yang berlaku, sementara voluntary disclosure merupakan pengungkapan aitem-aitem informasi yang dilakukan secara sukarela oleh perusahaan tanpa diwajibkan oleh peraturan yang berlaku. Berdasar Peraturan Otoritas Jasa Keuangan (POJK) Nomor 29/POJK.04/2016 Pasal 4 dikatakan bahwa pengungkapan wajib laporan keuangan emiten atau perusahaan publik sudah ditetapkan secara jelas dan lengkap, sedangkan untuk pengungkapan sukarela tidak ada standar baku yang mengaturnya. Gambaran strategi perusahaan dalam jangka panjang, indikator-indikator nonkeuangan penting yang berfungsi untuk meningkatkan efektifitas implementasi strategi perusahaan merupakan beberapa bagian dari voluntary disclosure (Wiguna \& Putri, 2016).

Perusahaan yang melakukan voluntary disclosure dalam laporan tahunannya dinilai mempunyai citra yang baik di mata investor (Amalia, 2005). Penelitian Oktriani \& Arza (2018) menunjukkan bahwa pengungkapan informasi yang diwajibkan belum mampu memuaskan kebutuhan investor sehingga mendorong perusahaan untuk mengungkap informasi tambahan secara sukarela.

Menurut Hanifah (2012) dan Syakhroza (2003), salah satu faktor yang memengaruhi voluntary disclosure adalah corporate governance (tata kelola perusahaan) yang mengacu pada prinsip transparant, accountable, responsible, independent, dan fairness. Berdasar PJOK nomor 30/POJK.05/2014 tentang tata kelola perusahaan pembiayaan, dikatakan bahwa perusahaan dituntut secara hukum untuk menerapkan konsep GCG yang didasari oleh prinsip keterbukaan (transparency), akuntabilitas (accountability), pertanggungjawaban (responsibility), kemandirian (independency), serta kesetaraan dan kewajaran (fairness). Kelima prinsip ini sangat penting karena penerapan GCG yang konsisten dapat meningkatkan kualitas laporan keuangan dan memberi sinyal positif kepada para pemodal.

Penelitian-penelitian mengenai pengaruh corporate governance terhadap voluntary disclosure menunjukkan kepemilikan manajerial memengaruhi pengungkapan sukarela perusahaan (Baek et al., 2009 dan Aini \& Syafruddin, 2015). Fatmawati et al. (2018) membuktikan dalam penelitiannya bahwa komite audit dan kepemilikan publik berpengaruh terhadap tingkat voluntary disclosure. Sementara itu, penelitian Fitriana \& Prastiwi (2014) menunjukkan bahwa proporsi dewan komisaris independen berpengaruh positif terhadap luas pengungkapan sukarela. Penelitian lain yang dilakukan oleh Oktriani \& Arza (2018) menemukan bahwa ownership dispersion berpengaruh negatif terhadap luasnya voluntary disclosure. Inkonsistensi antar hasil 
penelitian sebelumnya diduga tidak dilibatkannya variabel moderasi dan pengontrolan yang baik dalam model. Oleh karena itu, penelitian ini akan melakukan penyempurnaan dengan menguji kembali variabel-variabel corporate governance (kepemilikan manajerial, komite audit, dan komisaris independen) serta kepemilikan publik terhadap voluntary disclosure dengan menggunakan firm size sebagai pemoderasi sehingga diharapkan dapat memberi hasil pengujian yang lebih baik. Selain itu, penelitian ini juga mengontrol struktur modal perusahaan yang belum dilakukan pada penelitian-penelitian sebelumnya.

Menurut Suta \& Laksito (2012), total aktiva dapat menggambarkan besar kecilnya sebuah perusahaan (firm size). Perusahaan yang memiliki firm size besar cenderung memiliki tuntutan publik yang relatif tinggi. Hal ini dikarenakan semakin besar ukuran sebuah perusahaan, semakin banyak pemangku kepentingan yang terlibat, sehingga secara tidak langsung menuntut perusahaan untuk lebih terbuka dalam informasi. Kajian ini sejalan dengan penelitian yang dilakukan oleh Alhazaimeh et al. (2014) yang menunjukkan bahwa perusahaan besar mengungkapkan lebih banyak informasi sukarela daripada perusahaan kecil di Yordania. Temuan Oktriani \& Arza (2018) mendukung simpulan tersebut, yang menyatakan bahwa perusahaan dengan ukuran besar akan lebih terbuka dalam mengungkap informasi kepada publik dibandingkan perusahaan yang ukurannya kecil. Artikel ini diorganisasi menjadi 5 bagian, yang dimulai dari pendahuluan dan kajian literatur, kemudian dilanjutkan dengan metoda riset dan hasil penelitian, dan terakhir ditutup dengan simpulan, keterbatasan dan rekomendasi.

\section{KAJIAN LITERATUR}

\subsection{Kepemilikan Manajerial, Komite Audit, dan Voluntary Disclosure}

Menurut Pujiati \& Widanar (2009), kepemilikan manajerial merupakan proporsi saham dari pihak manajemen yang secara aktif ikut dalam pengambilan keputusan perusahaan. Kepemilikan manajerial diharapkan dapat mengatasi konflik keagenan (principal-agent) (Jensen $\&$ Meckling, 1976). Dengan adanya proporsi kepemilikan manajerial, manajer diharapkan dapat mengambil keputusan yang tidak mengandung moral hazard karena pada saat yang bersamaan manajer bertindak sebagai agen dan prinsipal (Yunita, 2012). Adanya kepentingan yang sama antara prinsipal dan agen melalui proporsi kepemilikan manajerial diharapkan membuat pengungkapan informasi menjadi lebih baik sehingga biaya keagenan dapat diminimalisir.

Penelitian yang dilakukan oleh Barros et al. (2013) menemukan bukti bahwa pengungkapan informasi perusahaan nonkeuangan di Perancis perioda 2006-2009 meningkat dengan adanya kepemilikan manajerial yang tinggi. Hal ini serupa dengan penelitian yang dilakukan oleh Li \& Qi (2008) yang menemukan bahwa 100 perusahaan nonkeuangan yang terdaftar di Cina periode 2003-2005 dengan proporsi kepemilikan manajerial yang tinggi cenderung memiliki tingkat voluntary disclosure yang juga tinggi. Dengan demikian, semakin tinggi proporsi saham yang dimiliki oleh para manajer, maka akan semakin tinggi voluntary disclosure suatu perusahaan. Temuan-temuan empiris tersebut memperkuat hipotesis pertama dalam penelitian ini yaitu kepemilikan manajerial berpengaruh positif terhadap voluntary disclosure.

Komite audit sebagai pihak independen berperan sebagai penghubung manajemen perusahaan dengan dewan komisaris maupun pihak luar lainnya melalui fungsi pengawasan, khususnya pengawasan terhadap manajemen perusahaaan (Onasis \& Robin, 2016). Penelitian 
Barako (2007) menunjukkan bahwa semua jenis pengungkapan informasi dipengaruhi oleh atribut good corporate governance, salah-satunya komite audit. Hal ini serupa dengan penelitian Bradbury (1990) yang menyatakan bahwa komite audit dipandang sebagai mekanisme pengawasan yang dapat meningkatkan fungsi audit dan pelaporan keuangan. Dengan demikian, komite audit dipersepsikan akan meningkatkan kualitas pengungkapan informasi suatu perusahaan. Uraian tersebut mendukung pengembangan hipotesis ke dua dalam riset ini yaitu komite audit berpengaruh positif terhadap voluntary disclosure.

\subsection{Komisaris Independen, Kepemilikan Publik, dan Voluntary Disclosure}

Komisaris independen merupakan anggota dewan komisaris yang tidak terafiliasi dengan direksi, anggota dewan komisaris lainnya, dan pemegang saham pengendali, serta bebas dari hubungan bisnis atau hubungan yang dapat memengaruhi kemampuannya untuk bertindak independen (Riniati, 2015). Komisaris independen bertugas melakukan pengawasan untuk mengakomodasi kepentingan para pemegang saham minoritas dan stakeholders lainnya. Jumlah komisaris independen dapat menjadi sinyal kepada para pemangku kepentingan bahwa fungsi pengawasan akan semakin baik.

Agustin \& Otavianna (2019) menemukan bahwa perusahaan akan lebih banyak melakukan pengungkapan sukarela dan tingkat pengawasan manajerial akan semakin efektif ketika semakin besar proporsi komisaris independen di dalam perusahaan. Hal ini dikarenakan semakin luas informasi yang diungkapkan akan semakin memudahkan komisaris independen dalam menjalankan fungsinya. Temuan-temuan empiris tersebut memperkuat hipotesis tiga dalam riset ini yaitu komisaris independen berpengaruh positif terhadap voluntary disclosure.

Kepemilikan publik dapat diartikan sebagai proporsi kepemilikan saham yang dimiliki masyarakat atau publik (Suta \& Laksito, 2012). Dalam hal ini, publik dapat diartikan sebagai pihak ekternal perusahaan yang tidak memiliki hubungan istimewa dengan perusahaan. Menurut Mujiyono \& Nany (2010), pengungkapan informasi lebih banyak diberikan oleh perusahaan yang sahamnya mayoritas dimiliki oleh publik. Dengan demikian, keluasan pengungkapan informasi oleh perusahaan dapat dipengaruhi oleh besar kecilnya proporsi saham yang dimiliki publik.

Penelitian Fatmawati et al. (2018) menemukan bahwa kepemilikan publik berpengaruh positif terhadap voluntary disclosure. Hal ini konsisten dengan penelitian Indriani (2013) yang menunjukkan bahwa porsi kepemilikan saham oleh publik berpengaruh terhadap luasnya voluntary disclosure. Monitoring publik secara tidak langsung akan mendorong perusahaan untuk memperluas pengungkapan sukarelanya guna meningkatkan kepercayaan publik. Kajian tersebut memperkuat argumentasi penulis dalam mengajukan hipotesis empat yaitu kepemilikan publik berpengaruh positif terhadap voluntary disclosure.

\subsection{Firm Size sebagai Pemoderasi}

Rahayuningsih \& Pujiono (2018) dalam artikelnya mengatakan bahwa pengungkapan informasi yang lebih luas cenderung dilakukan oleh perusahaan berskala besar dikarenakan risiko politisnya lebih tinggi. Ukuran perusahaan (firm size) berpotensi memicu konflik keagenan karena manajer dipersepsikan akan bertindak oportunis terhadap aset perusahaan yang besar. Untuk mengatasi hal tersebut, perusahaan perlu mengakomodir manajemen dengan kepemilikan manajerial sehingga konflik kepentingan dan biaya keagenan dapat diminimalisir. 
Pengaruh kepemilikan manajerial terhadap voluntary disclosure dalam kajian ini menunjukkan dapat dimoderasi oleh ukuran perusahaan. Semakin besar kepemilikan manajerial, semakin luas voluntary disclosure yang diungkapkan ketika diinteraksikan dengan ukuran perusahaan. Hal ini dikarenakan para manajer merasa ikut bertanggungjawab akan aset perusahaan yang besar.

Kondisi serupa juga terjadi pada komite audit. Tuntutan publik terhadap informasi yang simetris cenderung lebih tinggi pada perusahaan dengan firm size yang besar. Pada perusahaan yang ukurannya besar, tugas komite audit akan lebih kompleks sehingga perusahaan yang aktivanya besar idealnya memiliki jumlah komite audit yang lebih tinggi. Hal ini diyakini akan berpengaruh pada kualitas pengungkapan informasi perusahaannya. Argumentasi tersebut mengindikasi bahwa pengaruh komite audit terhadap luasnya pengungkapan sukarela dapat dimoderasi oleh ukuran perusahaan. Berdasar uraian tersebut, hipotesis ke lima yaitu firm size memoderasi pengaruh kepemilikan manajerial terhadap voluntary disclosure dan hipotesis ke enam yaitu Firm size memoderasi pengaruh komite audit terhadap voluntary disclosure.

Perusahaan yang memiliki total aset yang tinggi memerlukan pengawasan dan koordinasi yang baik, terutama dalam hal pengungkapan informasi perusahaan. Banyaknya jumlah komisaris independen memberi sinyal bahwa fungsi pengawasan dan koordinasi yang dilakukan semakin baik. Oleh karena itu, pengawasan pada perusahaan yang skalanya semakin besar akan lebih efektif apabila memiliki jumlah komisaris independen yang lebih banyak. Dengan demikian, pengaruh komisaris independen terhadap pengungkapan sukarela secara tidak langsung dapat dimoderasi oleh ukuran perusahaan.

Meningkatnya kepemilikan publik akan meningkatkan keluasaan informasi yang diungkap (Oktriani \& Arza, 2018). Sementara itu, perusahaan yang memiliki total aset yang lebih besar cenderung memiliki tuntutan keterbukaan informasi yang lebih tinggi dari publik. Feby (2017) dalam Oktriani \& Arza (2018) menjelaskan bahwa ukuran perusahaan yang besar akan meningkatkan jumlah stakeholder yang terlibat sehingga cenderung akan mendorong perusahaan melakukan pengungkapan informasi yang lebih luas.

Uraian tersebut mengidikasi bahwa pengaruh kepemilikan publik terhadap voluntary disclosure dapat dimoderasi oleh ukuran perusahaan. Perusahaan dengan total aset yang besar memiliki kegiatan usaha yang lebih kompleks sehingga berpotensi menimbulkan dampak yang besar bagi stakeholders. Semakin besar kepemilikan publik, maka semakin luas voluntary disclosure yang perlu diungkap apabila diinteraksikan dengan ukuran perusahaan. Uraian pada subbagian ini memperkuat argumentasi penulis dalam mengembangkan hipotesis ke tujuh dan hipotesis ke delapan dalam penelitian ini yaitu firm size memoderasi pengaruh komisaris independen terhadap voluntary disclosure dan firm size memoderasi pengaruh kepemilikan publik terhadap voluntary disclosure.

\section{METODE PENELITIAN}

Penelitian ini mengobservasi perusahaan-perusahaan yang tergabung dalam Indeks Kompas 100 di Bursa Efek Indonesia. Penggunaan indeks Kompas100 diharapkan dapat mewakili karakteristik pasar karena terdiri atas perusahaan-perusahaan liquid yang berkapitalisasi besar. Proses penyampelan dilakukan secara purposive dengan kriteria: (1) perusahaan sudah terdaftar di BEI minimal tahun 2014 dan secara konsisten masuk dalam Indeks Kompas100 pada perioda 
penelitian (2014-2018), dan (2) laporan keuangan tahunan menyajikan data yang berhubungan dengan kepemilikan manajerial, komite audit, komisaris independen, kepemilikan publik, dan aitem-aitem identifikasi voluntary disclosure. Berdasar kriteria tersebut, diperoleh jumlah observasi sebanyak 260 observasi (52 perusahaan x 5 tahun) sebelum pengecekan outlier data.

Hubungan antar variabel yang menjelaskan pengaruh variabel penjelas terhadap variabel terikat yang dimoderasi oleh firm size dapat dilihat dalam Model Penelitian berikut ini.

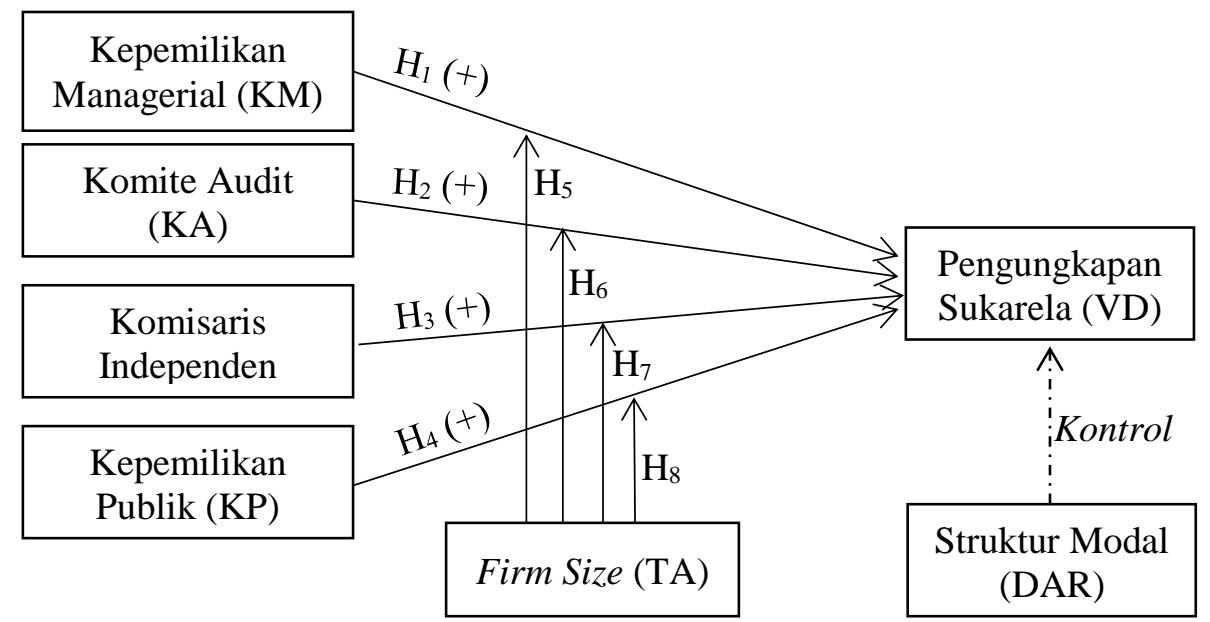

\section{Gambar 1. Model Penelitian}

Variabel Independen (bebas) dalam penelitian ini meliputi kepemilikan manajerial, komite audit, komisaris independen, dan kepemilikan publik. Sementara itu, variabel terikat yang diuji adalah voluntary disclosure. Penelitian ini juga menguji efek moderasi dengan melibatkan ukuran perusahaan yang dikontrol dengan struktur modal perusahaan (leverage). Secara rinci, operasional variabel-variabel terkait model riset pada Gambar 1 dapat dijelaskan sebagai berikut.

Tabel 1. Pengukuran Variabel Penelitian

\begin{tabular}{|c|c|c|}
\hline No & Variabel & Pengukuran \\
\hline 1 & $\begin{array}{l}\text { Kepemilikan } \\
\text { Manajerial }\end{array}$ & $\begin{array}{l}\text { Jumlah kepemilikan saham oleh manajemen dibagi jumlah saham beredar (Onasis } \\
\text { \& Robin, 2016) }\end{array}$ \\
\hline 2 & Komite Audit & Jumlah komite audit pada masing-masing perusahaan (Fatmawati et al., 2018). \\
\hline 3 & $\begin{array}{l}\text { Komisaris } \\
\text { Independen }\end{array}$ & $\begin{array}{l}\text { Jumlah komisaris independen dibagi jumlah seluruh komisaris (Sarafina \& Saifi, } \\
\text { 2017) }\end{array}$ \\
\hline 4 & $\begin{array}{l}\text { Kepemilikan } \\
\text { Publik }\end{array}$ & $\begin{array}{l}\text { Kepemilikan saham oleh publik dibagi jumlah saham perusahaan (Fatmawati } e \text { t } \\
\text { al., 2018) }\end{array}$ \\
\hline 5 & $\begin{array}{l}\text { Voluntary } \\
\text { Disclosure } \\
\text { (VD) }\end{array}$ & $\begin{array}{l}\text { Skor setiap aitem VD bersifat dikotomis ( } 1 \text { diungkap dan } 0 \text { tidak diungkap). Skor } \\
\text { yang diungkap dijumlahkan dan dibagi dengan total aitem VD yang diharapkan } \\
\text { (68 aitem) (Nuryaman, 2009). }\end{array}$ \\
\hline 6 & Firm Size & $\begin{array}{l}\text { Pengukuran dengan Ln Total Asset. Penggunaan proksi total aset dianggap lebih } \\
\text { stabil dibandingkan penjualan dan kapitalisasi pasar (Benardi et al., 2009). }\end{array}$ \\
\hline 7 & $\begin{array}{l}\text { Struktur } \\
\text { Modal } \\
(\text { Leverage })\end{array}$ & $\begin{array}{l}\text { Pengukuran menggunakan Debt to Total Assets Ratio (DAR), yaitu perbandingan } \\
\text { antara total kewajiban dengan total asset. }\end{array}$ \\
\hline
\end{tabular}

Pengujian model menggunakan Moderated Regression Analysis (MRA). MRA bertujuan untuk menentukan hubungan antara dua variabel atau lebih yang dipengaruhi variabel interaksi atau moderasi (Wiguna \& Putri, 2016). MRA dalam penelitian ini dapat menjelaskan apakah pemoderasi memperkuat atau memperlemah pengaruh variabel independen terhadap variabel 
dependen. Dengan menggunakan panel data, penelitian ini menguji empat model persamaan regresi yang masing-masing dapat dilihat pada bagian berikut ini.

Model 1:

$V D_{i t}=\alpha+\beta_{1} D A R_{i t}+\varepsilon_{i t}$

Model 2:

$V D_{i t}=\alpha+\beta_{7} T A_{i t}+\varepsilon_{i t}$

Model 3:

$V D_{i t}=\alpha+\beta_{2} K M_{i t}+\beta_{3} K A_{i t}+\beta_{4} K I N_{i t}+\beta_{5} K P_{i t}+\beta_{6} D A R_{i t}+\varepsilon_{i t}$

Model 4:

$\begin{aligned} V D_{i t}= & \alpha+\beta_{8} K M_{i t}+\beta_{9} K A_{i t}+\beta_{10} K I N_{i t}+\beta_{11} K P_{i t}+\beta_{12} T A_{i t}+\beta_{13} K M_{i t} * T A_{i t}+\beta_{14} K A_{i t} * T A_{i t}+\beta_{15} \\ & K I N_{i t} * T A_{i t}+\beta_{16} K P_{i t} * T A_{i t}+D A R_{i t}+\varepsilon_{i t}\end{aligned}$

Penjelasan notasi:

$\begin{array}{ll}V D_{i t} & =\text { Voluntary Disclosure } \\ \alpha & =\text { Konstanta } \\ \beta_{1}-\beta_{16} & =\text { Koefisien Regresi } \\ D A R_{i t} & =\text { Debt to Total Asset Ratio } \\ K M_{i t} & =\text { Kepemilikan Manajerial } \\ K A_{i t} & =\text { Komite Audit } \\ K I \mathrm{~N}_{i t} & =\text { Komisaris Independen } \\ K P_{i t} & =\text { Kepemilikan Publik } \\ T A_{i t} & =\text { Total Aset } \\ \varepsilon_{i t} & =\text { Residual }\end{array}$

\section{HASIL DAN PEMBAHASAN}

\subsection{Temuan dan Pembahasan Hipotesis}

Pengujian statistik dilakukan dengan menguji masing-masing model menggunakan bantuan perangkat lunak Eviews dan SPSS. Pengujian asumsi dasar dilakukan pada seluruh observasi dan ditemukan adanya pelanggaran pada linieritas parameter. Untuk memastikan model tidak bias maka dilakukan pengecekan outlier sehingga data akhir yang diuji dalam riset ini sebanyak 225 observasi. Observasi akhir tersebut telah memenuhi asumsi dasar sehingga dapat dilanjutkan pada pengujian selanjutnya.

Pengujian statistik dilakukan terhadap empat model regresi. Berdasar uji kelayakan dan spesifikasi model (goodness of fit model test), tampak bahwa keempat model tersebut memiliki goodness of fit yang baik. Hasil uji F mengindikasi semua model memenuhi spesifikasi kelayakan dengan tingkat signifikansi pada aras satu persen. Selain itu, nilai koefisien determinasi juga menunjukkan peningkatan yang baik dari keempat model tersebut, yang menunjukkan variasi variabel-variabel bebas dalam menjelaskan variasi variabel terikat cukup baik. Model satu menguji variabel struktur modal (leverage) yang diproksi dengan rasio total utang (DAR). Hasil regresi menunjukkan bahwa DAR berpengaruh positif terhadap keluasan pengungkapan sukarela (voluntary disclosure, VD) perusahaan pada aras satu persen. Hal ini mengindikasi bahwa variabel ini dapat digunakan sebagai pengendali dalam pengujian model-model selanjutnya. 
Tabel 2. Hasil Pengujian Model Penelitian

\begin{tabular}{|c|c|c|c|c|c|}
\hline No & Variabel & Model-1 & Model-2 & Model-3 & Model-4 \\
\hline \multirow[t]{2}{*}{1} & Konstanta & 79.256 & 38.096 & 42.968 & 149.5663 \\
\hline & Std. Error & $(0.767)^{*}$ & $(6.457)^{*}$ & $(7.362)^{*}$ & $(50.702)^{*}$ \\
\hline \multirow[t]{2}{*}{2} & KM & & & -0.549 & -9.682 \\
\hline & Std. Error & & & $(0.121)^{*}$ & $(4.419)^{*}$ \\
\hline \multirow[t]{2}{*}{3} & $\mathrm{KA}$ & & & 0.138 & 5.965 \\
\hline & Std. Error & & & $(.337)$ & $(6.507)$ \\
\hline \multirow[t]{2}{*}{4} & KIN & & & 0.038 & -0.959 \\
\hline & Std. Error & & & $(0.021) * * *$ & $(0.542)^{* * *}$ \\
\hline \multirow[t]{2}{*}{5} & $\mathrm{KP}$ & & & 0.040 & -1.669 \\
\hline & Std. Error & & & $(0.019)^{* *}$ & $(0.694)^{*}$ \\
\hline \multirow[t]{2}{*}{6} & TA & & 1.452 & 1.153 & -2.329 \\
\hline & Std. Error & & $(0.207)^{*}$ & $(0.260)^{*}$ & $(1.622)$ \\
\hline \multirow[t]{2}{*}{7} & $\mathrm{KM} * \mathrm{TA}$ & & & & 0.288 \\
\hline & Std. Error & & & & $(0.139)^{* *}$ \\
\hline \multirow[t]{2}{*}{8} & KA*TA & & & & -0.175 \\
\hline & Std. Error & & & & $(0.198)$ \\
\hline \multirow[t]{2}{*}{9} & KIN*TA & & & & 0.031 \\
\hline & Std. Error & & & & $(0.017) * * *$ \\
\hline \multirow[t]{2}{*}{10} & $\mathrm{KP} * \mathrm{TA}$ & & & & 0.055 \\
\hline & Std. Error & & & & $(0.022)^{*}$ \\
\hline \multirow[t]{2}{*}{11} & DAR & 7.969 & & 1.990 & 2.786 \\
\hline & Std. Error & $(1.364)^{*}$ & & $(1.583)$ & $(1.645)^{* * *}$ \\
\hline & $\mathrm{F}$ & 34.145 & 49.356 & 15.623 & 10,781 \\
\hline & (Sig.) & $(0.000)^{*}$ & $(0.000)^{*}$ & $(0.000)^{*}$ & $(0.000)^{*}$ \\
\hline & Adjusted $\mathrm{R}^{2}$ & 0.133 & 0.181 & 0.301 & 0.304 \\
\hline
\end{tabular}

Keterangan: Variabel Terikat $=$ VD $; * \operatorname{sig} .1 \% ; * * \operatorname{sig} .5 \% ; * * * \operatorname{sig} .10 \%$

Model dua menguji pengaruh ukuran perusahaan (TA) terhadap VD. Karena diposisikan sebagai pemoderasi (contingency) pada Model-4, maka TA juga harus dapat berperan sebagai prediktor. Hasil uji menunjukkan bahwa TA secara signifikan dan positif berpengaruh terhadap VD (signifikan pada aras satu persen). Skala perusahaan yang semakin besar akan mendorong keluasan pengungkapan variabel VD. Temuan ini memperkuat dukungan empiris bahwa TA diduga memiliki peran moderasi.

Pengujian pada model tiga melibatkan variabel Size (TA), DAR, kepemilikan publik (KP) dan good corporate governance (kepemilikan manajerial, komite audit, dan komisaris independen) terhadap VD. Hasil uji statistik menunjukkan tidak terdukungnya hipotesis pertama di mana kepemilikan manajerial yang sebelumnya diduga berpengaruh positif terhadap VD malah menunjukkan arah yang berbeda (pengaruh negatif). Hasil ini tidak sejalan dengan penelitian yang dilakukan oleh Barros et al. (2013) yang menyatakan bahwa pengungkapan informasi dalam laporan tahunan perusahaan nonkeuangan di Perancis perioda 2006-2009 meningkat seiring dengan peningkatan kepemilikan manajerial.

Inkonsistensi tersebut selanjutnya dianalisis lebih lanjut terhadap data observasi dalam riset ini. Observasi terhadap data kepemilikan manajerial menunjukkan varians yang kecil dengan rerata kepemilikan manajerial atas seluruh data observasi pada kisaran angka di bawah lima persen. Kepemilikan manajerial yang kecil tidak efektif dalam mengurangi konflik keagenan dan perilaku oportunistik. Hal ini menyebabkan manajemen tidak memiliki rentang kendali yang cukup dalam menentukan seberapa luas informasi sukarela akan diungkap. Analisis tersebut diduga menjadi 
salah satu penyebab inkonsistensi dengan temuan riset sebelumnya sehingga diperlukan kajian lebih mendalam terhadap variabel tersebut dalam konteks Indonesia.

Variabel good corporate governance (GCG) selanjutnya adalah komite audit (KA). Hasil analisis menunjukkan bahwa variabel KA bernilai positif tetapi tidak bermakna secara statistik terhadap VD. Temuan ini sekaligus menjelaskan bahwa meskipun komite audit dianggap efektif keberadaannya dalam meningkatkan fungsi pengawasan dan pemeriksaan suatu perusahaan, tidak bearti akan mampu mendorong perusahaan untuk melakukan pengungkapan sukarela yang lebih luas. Dengan demikian, hipotesis kedua tidak terdukung secara statistik sehingga dapat disimpulkan bahwa keberadaan komite audit tidak memengaruhi keluasan pengungkapan sukarela perusahaan.

Hasil output regresi Model-3 juga menunjukkan bahwa variabel GCG ke tiga yaitu komisaris independen (KIN) berpengaruh positif terhadap VD dengan tingkat signifikansi sepuluh persen. Hasil ini sejalan dengan riset Agustin \& Otavianna (2019) yang menyatakan bahwa pengungkapan sukarela dan pengawasan manajerial akan semakin efektif ketika jumlah komisaris independen meningkat di perusahan, kondisi ini akan mendorong semakin luasnya informasi yang diungkapkan ke publik. Temuan ini konsisten dengan hipotesis keempat yang dirumuskan dalam riset ini.

Variabel lain yang juga diuji dalam model tiga adalah kepemilikan publik (KP), ukuran perusahaan (TA), dan leverage (DAR). Hasil uji menunjukkan bahwa kepemilikan publik berpengaruh positif signifikan terhadap VD pada aras lima persen. Temuan ini menunjukkan bahwa sebaran kepemilikan publik yang semakin tinggi akan mendorong pengungkapan sukarela yang semakin luas, yang secara empiris mendukung rumusan hipotesis empat. Sementara itu, pada variabel ukuran perusahaan yang diproksi dengan total aktiva (TA) menunjukkan pengaruh positif signifkan terhadap VD dengan tingkat signifikansi satu persen. Hasil ini mengindikasi bahwa ukuran perusahaan yang semakin besar dapat mendukung pengungkapan sukarela yang semakin luas.

Variabel terakhir dalam model tiga adalah struktur modal perusahaan yang diproksi dengan DAR sebagai pengukur Leverage. Hasil uji menunjukkan koefisen DAR bertanda positif tetapi tidak bermakna secara statistik (aras signifikansi di atas 10 persen). Hal ini mengindikasi bahwa ketika digabung dalam model tiga bersama variabel KM, KA, KIN, KP, dan TA, leverage (DAR) tidak mendorong keluasan pengungkapan sukarela perusahaan terbuka di Indonesia.

\subsection{Efek Interaksi}

Model empat menguji efek interaksi antara variabel pemoderasi (TA) dengan semua variabel bebas. Pada saat diinteraksikan dengan Kepemilikan Manajerial (KM), tampak bahwa koefisien interaksi (KM*TA) bernilai positif signifikan pada aras 5 persen yang artinya size memoderasi pengaruh kepemilikan manajerial terhadap voluntary disclosure. Hasil pada model empat juga menunjukkan bahwa ketika belum diinteraksikan, variabel $\mathrm{KM}$ bertanda negatif signifkan pada aras satu persen, tetapi setelah diinteraksikan arah pengaruh KM menjadi positif signifikan. Temuan ini konsisten dengan rumusan hipotesis ke lima dalam riset ini dan secara tidak langsung mendukung temuan Rahayu \& Pujiono (2018).

Pengujian selanjutnya pada model empat menganalisis efek interaksi KA dengan TA. Hasil uji statiktik menemukan bahwa efek interaksi tidak tampak pada variabel komite audit 
(KA*TA) sehingga dukungan terhadap hipotesis enam tidak terkonfirmasi secara statistik. Pengujian variabel KA secara terpisah, baik pada Model-3 maupun Model-4 juga menunjukkan variabel TA tidak berpengaruh terhadap VD. Analisis ini mengindikasi bahwa TA hanya berpeluang menjadi pemoderasi potensial (homologiser moderator) terhadap variabel KA. Hal ini dikarenakan baik sebelum dan sesudah diinteraksikan, koefisien regresi untuk masing-masing variabel (KA dan KA*TA) tidak menunjukkan adanya nilai signifikansi.

Pengujian interaksi berikutnya dilakukan pada variabel Komisaris Independen (KIN*TA) dan Kepemilikan Publik (KP*TA). Sebelum diinteraksikan dengan ukuran perusahaan (TA), kedua variabel ini bernilai negatif signifikan (KIN pada aras 10 persen dan KP pada aras satu persen), yang menunjukkan inkonsistensi dengan konsep dan temuan-temuan empiris sebelumnya. Nilai koefisien (KIN*TA dan KP*TA) setelah diinteraksikan dengan TA selanjutnya menunjukkan arah yang berlawanan (bernilai positif sehingga konsisten dengan teori dan riset-riset terdahulu). Koefisien dari kedua variabel ini menunjukkan pengaruh positif dan signifikan masing-masing sebesar 10 persen (KIN*TA) dan satu persen (KP*TA).

Temuan ini mendukung riset Oktriani \& Arza (2018) dan Agustin \& Otavianna (2019). Menurut Oktriani \& Arza (2018), ukuran perusahaan dapat memperkuat pengaruh KP terhadap keluasan pengungkapan sukarela karena perusahaan yang memiliki total aset besar cenderung memiliki tuntutan publik yang tinggi, terutama dalam keterbukaan informasi sehingga tekanan terhadap perusahaan untuk mengungkapkan informasinya secara luas menjadi meningkat. Sementara itu, menurut Agustin \& Otavianna (2019), proporsi komisaris independen yang semakin besar akan mendorong manajemen melakukan pengungkapan sukarela yang lebih luas serta memiliki pengawasan manajerial yang lebih efektif.

Pengungkapan informasi sukarela yang semakin luas juga dapat dihubungkan dengan konsep signalling. Melalui perspektif signalling, manajemen dapat memberikan sinyal positif ke pasar untuk menarik kepercayaan pemodal terhadap prospek perkembangan perusahaan di masa depan dengan mengurangi asimetri informasi. Pengungkapan sukarela yang semakin luas merupakan salah satu cara yang dapat diambil oleh manajemen untuk mengurangi asimetri informasi.

Kajian empiris pada model empat mengindikasi bahwa TA sebagai proksi ukuran perusahaan memoderasi pengaruh KIN dan KP terhadap keluasan pengungkapan sukarela perusahaan terbuka di Indonesia dan cenderung memperkuat arah pengaruh. Temuan ini sekaligus menunjukkan dukungan terhadap rumusan hipotesis ke tujuh dan ke delapan dalam riset ini. Pengujian efek interaksi pada ke tiga variabel ini (KM, KIN, dan KP) mengindikasi bahwa ukuran perusahaan yang diproksi oleh TA memoderasi pengaruh kempemilikan manajerial, komisaris independen, dan kepemilikan publik terhadap keluasan pengungkapan sukarela perusahaanperusahaan terbuka di Indonesia.

Hasil uji pada model empat secara umum menunjukkan bahwa variabel TA dapat menjadi pemoderasi dalam menjelaskan anteseden pengungkapan sukarela perusahaan-perusahaan terbuka di Indonesia. Dalam kasus ini, efek interaksi yang ditunjukkan lebih mengarah pada interaksi semu (quasi moderator). Quasi moderasi menggambarkan sebuah variabel yang memoderasi pengaruh antara variabel bebas dengan variabel terikat, di mana pada saat yang bersamaan, pemoderasi tersebut juga berperan sebagai prediktor (independen) dalam model riset. 
Argumentasi ini diperkuat oleh temuan empiris dalam hasil regresi model tiga dan empat. Hasil tersebut menunjukkan bahwa sebelum diinteraksikan, variabel KM, KIN, dan KP masingmasing berpengaruh signifikan terhadap luasnya pengungkapan sukarela(VD). Selanjutnya, ketika masing-masing variabel diinteraksikan dengan TA, tampak bahwa nilai signifikansi $\mathrm{KM}^{*} \mathrm{TA}$ benilai positif signifkan pada angka 5\% (dari sebelumnya negatif signifikan yang tidak sesuai dengan konsep/teori). Sementara itu, variabel KIN*TA dan KP*TA tetap konsisten dengan konsep teoritis setelah diinteraksikan dengan TA, yang masing-masing menunjukkan pengaruh positif signifkan pada angka $10 \%$ dan $1 \%$.

\section{SIMPULAN DAN REKOMENDASI}

Berdasar hasil pengujian dan pembahasan, dapat disimpulkan bahwa ukuran perusahaan yang diproksi dengan total aset dapat memoderasi pengaruh kepemilikan publik dan tata kelola perusahaan (kepemilikan manajerial dan komisaris independen) terhadap pengungkapan sukarela. Hasil uji juga menunjukkan ukuran perusahaan berpotensi memoderasi pengaruh komite audit terhadap pengungkapan sukarela. Temuan statistik dalam riset ini mengonfirmasi bahwa setelah diinteraksikan dengan ukuran perusahaan, determinan pengungkapan sukarela perusahaan terbuka di Indonesia menunjukkan hasil yang lebih baik. Meskipun demikian, ukuran perusahaan diyakini bukan merupakan satu-satunya pemoderasi dalam menjelaskan determinan pengungkapan sukarela perusahaan terbuka di Indonesia sehingga perlu diteliti lebih lanjut.

Temuan dalam riset ini berimplikasi pada kebijakan manajerial perusahaan yang perlu mempertimbangkan tata kelola perusahaan yang baik dalam mendukung pengungkapan sukarela. Hal ini penting dilakukan mengingat berbagai bukti empiris telah menunjukkan adanya keterkaitan antara pengungkapan sukarela dengan nilai perusahaan. Pengungkapan sukarela yang semakin luas secara tidak langsung memberi sinyal positif ke pasar. Oleh karena itu, pemahaman terhadap determinan pengungkapan sukarela menjadi penting bagi manajemen perusahaan, termasuk efek interaksinya.

Riset ini tidak melakukan pengujian kehandalan model dengan menyimulasikan beberapa proksi pengganti sehingga generalisasi hasil riset belum optimal. Diperlukan penguatan validitas eksternal berupa replikasi, pengembangan model, dan penyempurnaan metoda riset untuk memperkuat implikasi managerial riset ini. Studi tentang pengungkapan sukarela dan kaitannya dengan nilai perusahaan menjadi penting dalam penelitian selanjutnya mengingat riset ini hanya berfokus pada anteseden dan efek interaksi variabel-varibael prediktor dalam menjelaskan isu pengungkapan sukarela perusahaan-perusahaan terbuka di Indonesia.

\section{UCAPAN TERIMA KASIH}

Terima kasih kepada FEB-UNTAN yang telah mendukung riset ini serta apresiasi yang tinggi kepada saudari Anggia Rizki Nurpratiwi atas berbagai kontribusi teknisnya.

\section{DAFTAR PUSTAKA}

Agustin, H. E., \& Otavianna, R. (2019). Pengaruh Porsi Kepemilikan Publik, Proporsi Dewan Komisaris Independen dan Ukuran KAP Terhadap Pengungkapan Sukarela. Jurrnal Akuntansi Berkelanjutan Indonesia, 2(1), 93-103. 
Aini, P. N., \& Syafruddin, M. (2015). Pengaruh Kepemilikan Manajerial Terhadap Pengungkapan Sukarela Dengan Efektivitas Komite Audit Sebagai Variabel Moderasi. Diponegoro Journal of Accounting, 4(2), 1-8. Retrieved from http://ejournals1.undip.ac.id/index.php/accounting

Alhazaimeh, A., Palaniappan, R., \& Almsafir, M. (2014). The Impact of Corporate Governance and Ownership Structure on Voluntary Disclosure in Annual Reports among Listed Jordanian Companies. Procedia - Social and Behavioral Sciences, 129, 341-348. https://doi.org/10.1016/j.sbspro.2014.03.686

Amalia, D. (2005). Faktor-faktor Yang Mempengaruhi Luas Pengungkapan Sukarela (Voluntary Disclosure) pada Laporan Tahunan yang Tercatat di Bursa Efek Jakarta. Jurnal Akuntansi Pemerintah, 1(2).

Astika, I. B. P. (2011). Konsep-konsep Dasar Akuntansi Keuangan. Udayana University Press.

Baek, H. Y., Johnson, D. R., \& Kim, J. W. (2009). Managerial Ownership, Corporate Governance and Voluntary Disclosure. Journal of Business \& Economic Studies, 15(2), 44-60.

Barako, D. G. (2007). Determinants of voluntary disclosures in Kenyan companies annual reports. African Journal of Business Management, 1(5), 113-128.

Barros, C. P., Boubaker, S., \& Hamrouni, A. (2013). Corporate governance and voluntary disclosure in France. The Journal of Applied Business Research, 29(2), 561-578.

Benardi, M., Sutrisno, \& Assih, P. (2009). Faktor-Faktor Yang Memengaruhi Luas Pengungkapan Dan Implikasinya Terhhadap Asimetri Informasi (Studi Pada Perusahaan-Perusahaan Sektor Manufaktur Yang Go Public Di Bursa Efek Indonesia). Simposium Nasional Akuntansi, 12.

Bradbury, M. E. (1990). The Incentives for Voluntary Audit Committee Formation. Journal of Accounting and Public Policy, 9(1), 19-36.

Fatmawati, R., Astuti, D. W., \& Suhardjanto, D. (2018). Peran Corporate Governance dalam Meningkatkan Voluntary Disclosure. Jurnal Akuntansi Multiparadigma, 9(1), 57-69. https://doi.org/10.18202/jamal.2018.04.9004

Fitriana, N. L., \& Andri Prastiwi. (2014). Faktor-Faktor Yang Mempengaruhi Luas Pengungkapan Sukarela Dalam Annual Report. Diponegoro Journal of Accounting, 3(3), 1-10. Retrieved from http://ejournal-s1.undip.ac.id/index.php/accounting

Hanifah, F. D. (2012). Pengaruh Corporate Governance, Kondisi Financial Distress dan Proprietary Cost Terhadap Luas Pengungkapan Sukarela Laporan Tahunan Perusahaan (Studi Empiris Pada Perusahaan yang Terdaftar Sebagai Peserta CGPI Tahun 20112104). 636-644. https://doi.org/10.1016/b978-0-12-373932-2.00098-3

Heriyanthi, I. G. A. R. (2013). Pengaruh Pengungkapan Sukarela Dan Manajemen Laba Pada Cost of Equity Capital Dengan Asimetri Informasi Sebagai Variabel Intervening. 2, 398416.

Indriani, E. W. (2013). Faktor-Faktor Yang Mempengaruhi Luas Pengungkapan Sukarela Dan Implikasinya Terhadap Asimetri Informasi. Accounting Analysis Journal, 2(2), 208-217. Retrieved from http://journal.unnes.ac.id/sju/index.php/aaj

Jensen, M. C., \& Meckling, W. H. (1976). Theory of The Firm: Managerial Behavior, Agency Cost, And Ownership Structure. Journal of Financial Economics, 3(4), 305-360.

Li, H., \& Qi, A. (2008). Impact of corporate governance on voluntary disclosure in Chinese listed companies. Corporate Ownership and Control, 5(2 D CONT. 3), 360-366. 
Mujiyono, \& Nany, M. (2010). Pengaruh Leverage, Saham Publik, Size Dan Komite Audit Terhadap Luas Pengungkapan Sukarela. Jurnal Dinamika Akuntansi, 2(2), 129-134. https://doi.org/10.15294/jda.v2i2.1936

Nuryaman. (2009). Pengaruh Konsentrasi Kepemilikan, Ukuran Perusahaan, Dan Mekanisme Corporate Governance Terhadap Pengungkapan Sukarela. Jurnal Akuntansi Dan Keuangan Indonesia, 6 (1). 89-116.

Oktriani, R., \& Arza, F. I. (2018). Pengaruh Listing Age dan Ownership Dispersion Terhadap Luas Pengungkapan Sukarela dengan Firm Size Sebagai Variabel Pemoderasi (Studi Empiris pada Perusahaan Manufaktur yang Terdaftar di BEI tahun 2014-2016). Jurnal WRA, 6(2), $1255-1270$.

Onasis, K., \& Robin, R. (2016). Pengaruh Tata Kelola Perusahaan terhadap Nilai Perusahaan pada Perusahaan Sektor Keuangan yang Terdaftar di BEI. Bina Ekonomi, 20(1), 1-22.

Pujiati, D., \& Widanar, E. (2009). Pengaruh Struktur Kepemilikan Terhadap Nilai Perusahaan: Keputusan Keuangan Sebagai Variabel Intervening. Jurnal Ekonomi Bisnis \& Akuntansi Ventura, 12(1), 71-86.

Putri, E. L. L. (2018). OJK Sedang Menangani 46 Kasus Pasar Modal. Kontan.Co.Id. Retrieved from https://investasi.kontan.co.id/news/ojk-sedang-menangani-46-kasus-pasar-modal

Rahayuningsih, H., \& Pujiono. (2018). Pengaruh Ukuran Perusahaan, Leverage dan Struktur Kepemilikan terhadap Integrated Reporting. Jurnal Akuntansi Unesa, 7(1), 1-25.

Riniati, K. (2015). Pengaruh Komisaris Independen dan Komite Audit terhadap Kinerja Perusahaan. Universitas Negeri Yogyakarta.

Sarafina, S., \& Saifi, M. (2017). Pengaruh Good Corporate Governance terhadap Kinerja Keuangan dan Nilai Perusahaan (Studi pada Badan Usaha Milik Negara yang terdaftar di Bursa Efek Indonesia Periode 2012-2015). Jurnal Administrasi Bisnis, 50(3), 108-117.

Sugiyono. (2013). Metode Penelitian Kuantitatif, Kualitatif Dan R\&D. Bandung: Alfabeta.

Sujarweni, V. W. (2015). Metodologi Penelitian Bisnis \& Ekonomi. Yogyakarta: PT. Pustaka Baru.

Suta, A. Y., \& Laksito, H. (2012). Analisis Faktor-Faktor Yang Mempengaruhi Luas Pengungkapan Informasi Sukarela Pada Laporan Tahunan. Diponegoro Journal of Accounting, 1(1), 1-15. https://doi.org/10.3275/8847

Syakhroza, A. (2003). Best Practices Corporate Governance Dalam Konteks Kondisi Lokal Perbankan Indonesia. Usahawan, 8(6).

Wiguna, I., \& Putri, I. G. A. (2016). Voluntary Disclosure Sebagai Pemoderasi Pengaruh Good Corporate Governance Terhadap Nilai Perusahaan. E-Jurnal Akuntansi, 17(3), 17001726.

Yunita, N. (2012). Pengaruh Corporate Governance Terhadap Voluntary Disclosure dan Biaya Hutang. Jurnal Ilmiah Mahasiswa Akuntansi, 1(1), 90-96. 